\title{
Clinical and Laboratory Changes of Patients with Various Diseases Treated by SVATE-3.
}

Sjukri Karim

\begin{abstract}
Abstrak
Snake Venom Anti Thrombus Enzyme-3 (SVATE-3) telah dipakai secara luas dalam klinik pada berbagai penyakit, dan dikatakan memiliki efek samping yang ringan. Telah dilakukan penilaian efek SVATE-3 pada gejala klinik, hemoreologi, kadar lemak darah dan fungsi hati pada 12 penderita (11 laki-laki dan 1 wanita) yang semuanya memiliki gejala penyakit dan hemodinamik stabil, umur 42-70 tahun, semua mendapat pengobatan SVATE-3 selama 21 hari sesuai protokol. Selama pengobatan dengan SVATE-3 tidak ada perubahan obat-obatan yang sedang digunakan oleh penderita. Hasil yang diperoleh menunjukkan bahwa efektivitas SVATE-3 berdasarkan perbaikan gejala klinik adalah $89.5 \%$. Tidak terdapat perbedaan yang bermakna secara statistik sebelum dan sesudah pengobatan

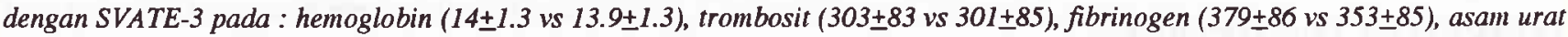

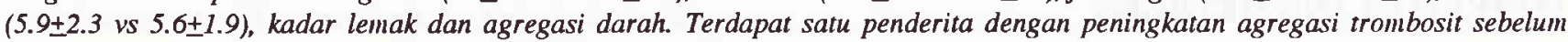
pengobatan yang menjadi normal setelah pemberian SVATE-3. Terdapat penurunan bermakna pada kadar SGOT (20.5 \pm 3 vs $13.7 \pm 2)$

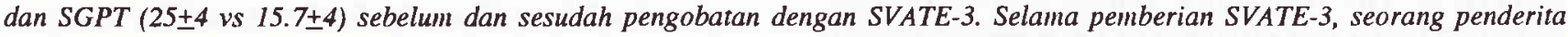
mengalami gejala alergi yang dapat diatasi dengan pemberian antihistamin. Tidak ditemukan tanda-tanda perdarahan. Sehingga disimpulkan bahwa pengobatan dengan SVATE-3 pada penderita yang kondisi penyakitnya stabil dapat memperbaiki gejala penyakit tanpa menimbulkan efek samping yang berarti.
\end{abstract}

\begin{abstract}
Snake Venom Anti Thrombus Enzyme-3 (SVATE-3) has already been widely used in the clinic for various diseases, and has been claimed to have less side-effects. We investigated the effect of SVATE-3 on the clinical symptoms, hemorrheology, lipid profile and liver function. Twelve patients (11 male and 1 fernale) who were symptomatically and hemodynamically stable, aged 42-70 years, all of whom received a 21-day SVATE-3 treatment according to the protocol, were studied. During the treatment, there were no alteration of medication which had been used by these patients. The result showed that the effectiveness of SVATE-3 treatment based on the improvement of symptom is $89,5 \%$. There were no statistically difference before and after SVATE-3 treatment on haemoglobin (14 1.3

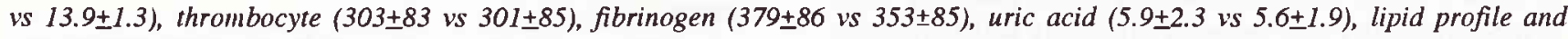
aggregation. In fact, one patient who had an increased thrombocyte aggregation before treatment, which become normal after treatment.

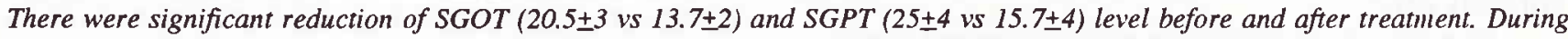
treatment, one patient suffered from allergy that was controlled by antihistamin. There were no sign of bleeding reported. We concluded that SVATE-3 treatment in patients with stable condition may improve clinical symptoms without serious side effects.
\end{abstract}

Key words: Snake Venom Anti Thrombus Enzyme, hemorhoelogy, lipid profile, liver function.

\section{INTRODUCTION}

The purified enzyme extracted from snake venom (Ancrod) had been used clinically to tread thrombotic disease since 1968, and has been included in the British Pharmacopea published in 1973. ${ }^{1}$

The Snake Venom Anti Thrombus Enzyme (SVATE) was later developed in China by Hao Wen-
Xue et al. ${ }^{2}$ This drug has been shown to possess many functions such as: anticoagulation, thrombolysis, dilating blood vessels, lowering blood fat, promoting nerve growth, and anti senility. And has been reported successful in treating cerebral thrombosis, acute myocardial infarction, unstable angina, hypercholesterolaemia, diabetes mellitus, Raynaud disease and senile diseases. ${ }^{3}$ The major side effect of SVATE is bleeding 
because of its thrombolytic effect, and because it contains neurotoxin, it therefore can also cause dizziness, fever, numbness etc.

SVATE-3 is a new refined product of SVATE extracted from Agkistrodon Hyals by a better technological process, of which the factory has claimed to have less side-effect or adverse reaction for the majority of patients.

Since SVATE-3 has gained popularity in our community, and has been frequently used by doctors in Jakarta in treating various diseases, we therefore would like to investigate the effectiveness of SVATE3 treatment, and more importantly if there are any side-effects of SVATE-3 occuring in patients.

\section{MATERIALS AND METHODS}

SVATE-3: The frozen-dry venine powder of $\mathrm{Ag}$ kistrodon Hyals was provided by the Research Center of Prevention and Treatment of Senile Diseases of China Medical University. Each ampule containing $100 \mathrm{usp} / \mathrm{ml}$ (0.25 unit) of arginine esterase activity.

Subjects: Patients who came to the Preventive Cardiology Unit, National Cardiac Center, Jakarta, seeking for SVATE-3 treatment, had either heard from their friend, or sent by doctors will be selected. The diagnoses were based on history taking, physical and laboratory examinations, or data presented by patients themselve. The inclusion criteria was : the patiens had to be in a stable condition, which meant that they were symptomatically and hemodynamically stable (no one critically ill).

Sample selection: Twelve patiens were randomly selected from a total of 43 patient who finished a 21-day course of SVATE-3 treatment during 1stNovember-1993 to 31st-December-1993. Because the study was designed to compare means in paired group, in which subjects were measured or observed twice, the formula used to estimate sample size was based on Dawson-Saunders and Trapp (1990); for a study with a $\mathrm{P}$-value of 0.05 , and experiment will have a $90 \%$ chance of detecting an actual difference between the two groups, the sample of 12 patients should be sufficient. ${ }^{4}$

Study procedure: All patiens should maintain their medication until the end of the SVATE- 3 treatment. Blood sample for examination of hemorrheology, lipid profile, liver and kidney functions were taken at the begining and at the end of SVATE-3 treatment. Before SVATE-3 treatment, informed consent will be sought after the anticipated benefit and potential hazards of the treatment and discomfort it may entail were explained to the patiens by the doctor. The questionaire was given to every patient for answer- ing about their health status, symptoms and activity before, during and after SVATE-3 treatment.

The effect of treatment was judged by the alteration of symptoms, which is devided into four groups, that are : worse, no change, improve and marked improve.

The SVATE- 3 treatment: SVATE- 3 was given as recommended, that was 4 ampules a day for patients weight under $60 \mathrm{Kg}$, and 8 ampules a day for patients heavier than $60 \mathrm{Kg}$. The drug was disolved in normal saline, that are 4 ampules in $10 \mathrm{ml}$ administered intravenously directly, and another 4 ampules in $250 \mathrm{ml}$ of normal saline and administered intravenously with the rate of 45 drops/minute. All patients received a 21-day course of SVATE-3 treatment.

Statistics: The data were presented as mean and standard deviation of the mean. The statistical significance of difference between pairs of means was determined by paired Student's t-test. The analyses were performed using the computer programe CSS (Statsoft, Tulsa, ESA) run under the MS-DOS 3.3 operating system. In all cases, level of probability (P) of less than 0,05 were taken to indicate significance.

\section{RESULTS}

Twelve patients $(28 \%)$ of a total of 43 patient were enrolled in this study. Baseline characteristic of patients was shown in table 1. Most patients suffered from coronary artery disease with the addition of other diseases.

After a 21-day course of Svate-3 treatment, the therapeutic effects based on clinical symptoms were determined. The overall effectiveness rate was $89,5 \%$ (Table 2).

SVATE- 3 treatment did not result in any alteration of the principle biochemical and hematological data, in particular the haemoglobin level, the platelet count, haemotocrit, and the kidney function test. The SGOT and SGPT level were lower after SVATE-3 treatment (Table 3).

Table 4 summarizes the result of platelets aggregation; there were no statistically difference in the extent of ADP-induced aggregation before and after SVATE-3 treatment. One patient who had an increased thrombocyte aggregation before treatment become normal after treatment.

There were not any changes on the lipid profile before and after SVATE-3 treatment (Table 5).

No patients witheld a 21-day course of SVATEtreatment because of side-effects.

During treatment, there were no any spontaneous bleeding or neurological symptoms reported, except one patients who had a rash and itch after the injection that can be controlled by antihistamin. 
Table 1. Demographic and clinical characteristic $(n=12)$

\begin{tabular}{|c|c|c|c|}
\hline Variable & Number & Mean & SD \\
\hline Age (years) & & 59,5 & 9 \\
\hline Male & 11 & & \\
\hline Sex & & & \\
\hline Female & 1 & & \\
\hline HR $(x / \min )$ & & 74 & 11 \\
\hline Systolic (mmHg) & & 132 & 17 \\
\hline Diastolic (mmHg) & & 83 & 10 \\
\hline Coronary Artery Disease & 10 & & \\
\hline Non-haemorhagic Stroke & 1 & & \\
\hline Stenosis a. Carotic Communis & 1 & & \\
\hline Parkinsonism & 1 & & \\
\hline History of Hypertension & 4 & & \\
\hline Diabetes Mellitus & 2 & & \\
\hline
\end{tabular}

Table 2. Comparison of symptoms before \& after SVATE-3 treatment $(n=12)$

Note : some patients have more than 1 symptom

\begin{tabular}{|c|c|c|c|c|c|c|}
\hline \multirow[t]{2}{*}{ Item } & \multirow{2}{*}{$\begin{array}{l}\text { no. of } \\
\text { case }\end{array}$} & \multicolumn{4}{|c|}{ changes after treatment } & \multirow{2}{*}{$\frac{\text { effective }}{\text { rate }}$} \\
\hline & & worse & $\begin{array}{c}\text { no } \\
\text { change }\end{array}$ & improve & $\begin{array}{l}\text { market } \\
\text { improve }\end{array}$ & \\
\hline Angina & 9 & 0 & 1 & 7 & 1 & $88.8 \%$ \\
\hline Paresthesia & 4 & 0 & 1 & 2 & 1 & $75 \%$ \\
\hline Insomnia & 2 & 0 & 0 & 2 & 0 & $100 \%$ \\
\hline Dyzzyness & 1 & 0 & 0 & 1 & 0 & $100 \%$ \\
\hline Short of breath & 2 & 0 & 0 & 2 & 0 & $100 \%$ \\
\hline Tremor & 1 & 0 & 0 & 1 & 0 & $100 \%$ \\
\hline Total & 19 & 0 & 2 & 15 & 2 & $89.5 \%$ \\
\hline
\end{tabular}

Table 3. Comparison of haematological data before and after treatment of SVATE-3 $(n=12)$

\begin{tabular}{|c|c|c|c|c|c|}
\hline & \multicolumn{2}{|c|}{ Before } & \multicolumn{2}{|c|}{ After } & \multirow{2}{*}{ P-Value } \\
\hline & Mean & $\pm S D$ & Mean & SD & \\
\hline Haemaglobin & 14 & 1,3 & 13,9 & 1,3 & NS \\
\hline Leucocyte & 6370 & 1086 & 6500 & 975 & NS \\
\hline Haematocrite & 44 & 4,1 & 42 & 3,7 & NS \\
\hline S G P T & 20,5 & 3 & 13,7 & 2 & $<0,05$ \\
\hline S GOT & 25 & 4 & 15,7 & 4 & $<0,05$ \\
\hline Ureum & 33,3 & 13 & 33,9 & 12 & NS \\
\hline Creatinine & 1,38 & 0,3 & 1,42 & 0,3 & NS \\
\hline Uric Acid & 5,9 & 2,3 & 5,6 & 1,9 & NS \\
\hline
\end{tabular}

Table 4. Comparison of platelet aggregation in whole blood $(n=12)$ before and after the SVATE-3 treatment

\begin{tabular}{|c|c|c|c|c|c|}
\hline & \multicolumn{2}{|c|}{ Before } & \multicolumn{2}{|c|}{ After } & \multirow[b]{2}{*}{ P-Valut } \\
\hline & Mean & SD & Mean & SD & \\
\hline Thrombocyte & 302,7 & 83 & 301,1 & 85 & $>0,05$ \\
\hline Fibrinogen & 379,2 & 86 & 353,6 & 85 & $>0,05$ \\
\hline \multicolumn{6}{|l|}{ Platelet Aggregation } \\
\hline Agg. $\max$ ADP $5 \mathrm{~mm}$ & 30,4 & 17,6 & 29,4 & 13,5 & $>0,05$ \\
\hline Time & $1 ' 17^{\prime \prime}$ & $0.34^{\prime \prime}$ & $18^{\prime \prime}$ & $0.07 "$ & $>0,05$ \\
\hline Agg. $\max$ ADP $10 \mathrm{~mm}$ & 38,1 & 18,5 & 35,6 & 14,5 & $>0,05$ \\
\hline Time & $1^{\prime} 14^{\prime \prime}$ & $0.51 "$ & $1^{\prime} 19^{\prime \prime}$ & $0.23^{\prime \prime}$ & $>0,05$ \\
\hline Reversibilitas & 29,2 & 12 & 27,3 & 10,9 & $>0,05$ \\
\hline
\end{tabular}

Table 5. Comparison of lipid profile before and after the SVATE-3 treatment

\begin{tabular}{|c|c|c|c|c|c|}
\hline & \multicolumn{2}{|c|}{ Before } & \multicolumn{2}{|c|}{ After } & \multirow{2}{*}{ P-Value } \\
\hline & Mean & SD & Mean & SD & \\
\hline Cholesterol total & 215,8 & 44 & 211,1 & 42 & $>0,05$ \\
\hline H D L & 37,6 & 13 & 39,6 & 14 & $>0,05$ \\
\hline L D L & 148,2 & 38 & 145 & 41 & $>0,05$ \\
\hline Total cholesterol/HDL & 6,3 & 2 & 5,8 & 1,8 & $>0,05$ \\
\hline Triglyceride & 143,6 & 65 & 125,2 & 50 & $>0,05$ \\
\hline
\end{tabular}

\section{DISCUSSION}

Platelet mediated thrombus is a main patho-genetic mechanism that limits the efficacy of thrombolytic agents such as streptokinase or tissue plaminogen activator, because these agents also stimulate coagulation. ${ }^{5}$ Attempts to isolate the more effective anti thrombotic agent to treat or to prevent platelet-mediated thromboembolism is therefore developed, including the use of aspirin, protagladin E, selective thromboxame $\mathrm{A} 2$ receptor antagonsts, hirudin and the latest, SVATE-3.

Svate- 3 has been widely used in the treatment of thromboembolic diseases in China. It possesses several anti thromboembolic functions such as anticoagulation, thrombolysis, and dilating blood vessels. ${ }^{2,6}$ It has been shown that Kistrin obtained from the venom of Agkistrodon Rhodostroma is the specific human platelet $\mathrm{GP}_{\mathrm{IIb} / \mathrm{III} a}$ receptor antagonist that inhibit platelet aggregation. ${ }^{7}$ SVATE- 3 which is also isolated from the venom of Agkistrodon may have platelet GP IIb/IIIa antagonist activity; on top of the thrombolytic effect, especially for old thrombus, ${ }^{B}$ SVATE-3 may accelerate the lysis as well as prevent 
the reocclusion of thromboembolism. Thus, it seems reasonable to use SVATE-3 in treating thromboembolic diseases.

The clinical presentation of thromboembolic disease is dependent on where the target organ is affected; cramps or muscle pain in the limb may indicate the occlution of arterial circulation in the extremities. Intermitten neurological dysfunction usually associate with cerebral thrombus. Seventeen percent patients with coronary artery disease had been demonstrated to have thrombus around the atherosclerotic plaque. ${ }^{9}$ These patients are therefore selected for SVATE-3 treatment in our clinic.

Because SVATE-3 is a relatively new agent in Indonesia, in order to avoid untoward effects, the patients chosen in this study were all in stable condition.

It has been reported that hemorrheology and lipid profile of patients with cerebrothrombosis dropped significantly after the SVATE-3 treatment. ${ }^{10}$ In this study, we found no alteration of the hemorrheology (Table 4) and lipid profile (Table 5) in patients who received a 21-day course of SVATE-3 treatment. This discrepancy may be due to the differebce in population selection; In this study, the patients were all in the stable condition, while previous studies investigated with ill patients. In the acute or subacute disease stage, the aggregation process or others blood biochemistry are more activated, ${ }^{11}$ therefore the inhibitory effect of SVATE-3 may become more pronounce compared to a stable condition. Previous study has shown that the intravenous (I.V) and intraperitoneal (I.P) LD $\mathrm{LD}_{50}$ of SVATE- 3 for mouse were $1930 \pm 177 \mathrm{usp} / \mathrm{KgBw}$, and $825 \pm 73 \mathrm{usp} / \mathrm{KgBw}$, respectively. By using 20 usp/KgBw/day of SVATE-3 to treat rabbits for a-3month period showed no differences on the ability of movement, the rate of gaining weight, the last survival rate and the hepatic function compared to control group. $^{12}$ The dosage of SVATE-3 recommended for clinical use is $2-10 \mathrm{usp} / \mathrm{KgBw}$ each time which is 200 times lower than LD50. It has been reported that there were no untoward reaction found in patients treated with large dose of SVATE-3, that was $1 \mathrm{u}$ (4 ampules) on first day, then continued by 2 u ( 8 ampules) every day for one and half months. ${ }^{10}$ Based on this result and clinical findings, SVATE-3 seems to be a safe agent. This is in accord with the present study that no one of our patients had complained of side effect, no spontanous bleeding or neurological symptoms occured.

The haemoglobin, platelet count, kidney function were unchanged before and after SVATE- 3 treatment (Table 3).
The decreased SGOT and SGPT level is interesting, further research should be carried out to see whether SVATE-3 would decrease the SGOT and SGPT level in patients with hepatic disease.

Nevertheless, present study showed that SVATE3 treatment at the recommended dosage in patients with stable condition of thromboembolic diseases may improve symptom and without any serious side effect. Further large scale experiments are needed to comfirm this preliminary result.

\section{REFERENCES}

1. Martindale. The Extra Pharmacopea. Twenty-sixth edition, Amendments, London, The Pharmaceutical Press 1973; 866.

2. Hao W-X. Effect of arginine lipidase extracted from the Mamushi of snake island (She Dao) of China on blood in dogs. The Snake 1981; 13: 113-6.

3. Chen Y-C. Comparison of refined Angkistrodon Hyals Anti Thrombus Enzyme-3 (SVATE-3) and Agkistrodon Hyals Pallas Anti Thrombus Enzume-2 (SVATE-2). In: The compilation of achievements in scientific research of refined anti thrombus enzyme-3 (SVATE-3). China Medical University 1991: 1-9.

4. Dawson-Saunders B \& Trapp RG : Basic and clinical Biostatistic, chapter 7, A Lange Medical Book, 1990: 99-123.

5. Gulba DC, Barthels M, Westhoff-Black M, Jost S, Raffienbeul W \& Dankl WG. Increased thrombin level during thrombolytic therapy in acute myocardial infarction. Circulation 1991; 83: 937-44.

6. Hao W-X. The Development of Snake Anti Thrombus Enzyme Research. Dalian SVATE Pharmaceutical Bulletin 1991: 1-4.

7. Yasuda T, Gold HK, Leinbach RC et al.: Kistrin, a polipeptide platelet GP IIb/IIIa receptor antagonist, exchances and sustains coronary arterial thrombolysis with recombinant tissue-type plasminogen activator in a canine preparation. Circulation 1991; 83: 1038-47.

8. Pan WM. Experimental research of the thrombolytic effect of snake venom antithrombus enzyme on the coronary thrombus in dogs. In: The compilation of achievements in scientific research of refined anti thrombus enzyme-3 (SVATE-3). China Medical University 1991: 10-43.

9. Davies MJ, Bland JM, Hangartner JRW, Angelini A \& Thomas AC. Factor influencing the presence or absence of acute coronary artery thrombi in sudden ischemic death. Eur. Heart J 1989; 10: 203-8.

10. Qu J-H \& Lu Y-Y. Clinical observation on the treatment of 667 cases of cerebro thrombosis with Svate-3. China medical University Press 1989; 18: 41-50.

11. Muller HS, Rao PS and Greenberg MA. Systemic and transcardiac platelet activity in acute myocardial infarction in man resistance to prostacyclin. Circulation $1985 ; 72$ : 1336-9.

12. Zhan L-F. Astudy of SVATE-3 for acute and subchronic toxicology. In: The compilation of achievements in scientific research of refined antithrombus enzymes-3 (SVATE-3). China Medical University 1991: 73-86. 